\title{
Erratum to: Echocardiography for adult patients supported with extracorporeal membrane oxygenation
}

\author{
Ghislaine Douflé ${ }^{1,2^{*}}$, Andrew Roscoe ${ }^{3}$, Filio Billia ${ }^{2,4}$ and Eddy Fan ${ }^{1,2}$
}

Upon publication of this article [1] it has been found that the additional files published out of order by mistake. This has now been corrected.

In addition we updated a minor error in the legend for additional file 24:

'Additional file 24. Video S19. Patient on VA ECMO. Parasternal short axis at the level of the aortic valve of the same patient as in Additional files 22 and 23. LA vent cannula seen is the LA through the IAS.'

The legend is now correctly referring to additional files 22 and 23 , rather than 22 and 18 as before.

\section{Author details \\ ${ }^{1}$ Interdepartmental Division of Critical Care Medicine, University of Toronto, Toronto, ON M5G 2N2, Canada. ${ }^{2}$ Extracorporeal Life Support (ECLS) Program, Toronto General Hospital, Toronto, ON M5G 2N2, Canada. ${ }^{3}$ Department of Anaesthesia \& ICU, Papworth Hospital, Cambridge CB23 3RE, UK. ${ }^{4}$ Peter Munk Cardiac Centre, University Health Network, Toronto, ON M5G 2N2, Canada.}

Received: 3 February 2016 Accepted: 3 February 2016

Published online: 08 February 2016

\section{Reference}

1. Douflé G, Roscoe A, Billia F, Fan E. Echocardiography for adult patients supported with extracorporeal membrane oxygenation. Crit Care. 2015;19:326.

\footnotetext{
* Correspondence: ghislaine.doufle@uhn.ca

'Interdepartmental Division of Critical Care Medicine, University of Toronto, Toronto, ON M5G 2N2, Canada

${ }^{2}$ Extracorporeal Life Support (ECLS) Program, Toronto General Hospital,

Toronto, ON M5G 2N2, Canada

Submit your next manuscript to BioMed Central and we will help you at every step:

- We accept pre-submission inquiries

- Our selector tool helps you to find the most relevant journal

- We provide round the clock customer support

- Convenient online submission

- Thorough peer review

- Inclusion in PubMed and all major indexing services

- Maximum visibility for your research

Submit your manuscript at

www.biomedcentral.com/submit 